\title{
Effect of Different Levels of NPK and Vermicompost on Physico-Chemical Properties of Maize [Zea mays (L.)] Cv. MM2255
}

\author{
Vinod Kumar Prajapati* and Narendra Swaroop
}

Department of Soil Science, Sam Higginbottom Institute of Agriculture, Technology \& Sciences (Deemed-to-be-University), Allahabad, 211007 U. P., India

*Corresponding author

\section{A B S T R A C T}

\begin{tabular}{|l|}
\hline Ke y w o r d s \\
Soil properties, \\
Nutrients sources, \\
NPK and \\
Vermicompost \\
content, Maize etc. \\
\hline Article Info \\
\hline Accepted: \\
15 January 2018 \\
Available Online: \\
10 February 2018 \\
\hline
\end{tabular}

\section{Introduction}

Maize (Zea mays L.) belongs to Gramineae family maize is considered as the native to the Central America and Mexico where many diverse types of maize are found Rai (2006). Maize is one of most important cereal crop in the world agriculture Economy both as food for man and feed for animal. It is a miracle crop. It has very high yield potential. There is no cereal on the earth which has so immense potentiality and that is why it is called "queen of cereals" maize is grown in almost all the states of India. Maize grain contains about $10 \%$ protein, $4 \%$ oil, $70 \%$ carbohydrate $2.3 \%$ crude fiber, $10.4 \%$ aluminizes, $1.4 \%$ ash.
Maize protein 'Zein' is in tryptophan and lysine two essential amino acids Singh et al., (2007). Excessive use of chemical fertilizers, decline in soil and food quality due to loss of soil organic matter is the main characteristics of the conventional farming systems which are more pronounced in arid and semi-arid areas (Singh et al., 2007; Melero et al., 2008; Liu et al., 2009). Increasing public awareness of the negative environment an impacts, growing consumer demand for healthier products and criticism of high input production systems. Alternate agricultural practices such as organic farming, eco-farming, biodynamic farming and traditional farming practices are considered important alternatives to increase 
soil fertility and soil health. Inorganic farming the application of organic manure especially vermicompost is recommended. It is ecofriendly, non-toxic, consumes low energy input for composting and is a recycled biological product (Lourduraj and Yadav, 2005). Vermicomposts are organic materials broken down by interactions between microorganism and earthworms in a mesophilic process (up to $25^{\circ} \mathrm{C}$ ), to produce fully stabilized organic soil amendments with low $\mathrm{C}$ : $\mathrm{N}$ ratios. They have a high and diverse microbial and enzymatic activity, fine particulate structure, good moisture-holding capacity, and contain nutrients such as N, P, $\mathrm{K}, \mathrm{Ca}$ and $\mathrm{Mg}$ informs readily taken up by plants (Lavelle and Martin, 1992; Prabha et al., 2005; Arancon and Edwards, 2009).

The application of vermicompost helps to improves and conserves the fertility of soil. Vermicompost imparts a dark colour of the soil and thereby help to maintain the temperature of soil. Vermicompost is one of the manure used by the farmer in growing crops because of early availability and presence of almost all the nutrients required by plants. The composition of vermicompost is $0.6-1.2 \% \mathrm{~N}, 0.13-0.22 \% \mathrm{P}$ and $0.40-0.75 \%$ K Pawar. (2007). Nitrogen is a most important element for the synthesis of protoplasm, which is responsible for rapid cell division (plant shape and size).

It increased the production of grain yield in maize as well as it is important for the quality of produce like increase proteins in grain. It increases utilization of $\mathrm{P}$ and $\mathrm{K}$ to an appreciable extent Singh et al., (2003). Phosphorus its plays a vital role in photosynthesis, respiration, energy storage transfer cell division, cell elongation and several other processes in living plants. Phosphorus is also a structural component of the cell constituents and metabolically active compound Ahmad et al., (2004). Potassium maintains the cellular organization by regularity the permeability of cellular membrane and keeping the protoplasm in a proper degree of hydration by stabilizing the emulsion of highly colloidal particles. Thus help in maintaining turgor pressure and eliminates water imbalance in plants Singh et al., (2003).

\section{Materials and Methods}

A field Experiment was conducted on research farm of department of Soil Science, Allahabad School of Agriculture, Sam Higginbottom Institute of Agriculture, Technology and Sciences (Deemed-to-be-University) Allahabad, (U.P.) India. The soil of experimental area falls in order Inceptisol and the experimental field is alluvial in nature.

The design applied for statistical analysis was carried out with $3^{2}$ factorial randomized block design having three factors with three levels of NPK @ 0, 50, and 100\% ha ${ }^{-1}$, three levels of Vermicompost@0, 50 and 100\% ha $^{-}$ ${ }^{1}$ respectively. Treatments were $\mathrm{T}_{0-}\left(\mathrm{L}_{0} \mathrm{~V}_{0}\right) @ 0$ $\%$ NPK ha ${ }^{-1}+0 \%$ Vermicompost ha ${ }^{-1}, \mathrm{~T}_{1}-$ $\left(\mathrm{L}_{0} \mathrm{~V}_{1}\right) @ 0 \% \mathrm{NPK} \mathrm{ha}^{-1}+50 \%$ Vermicompost $\mathrm{ha}^{-1}, \mathrm{~T}_{2}-\left(\mathrm{L}_{0} \mathrm{~V}_{2}\right) @ 0 \% \mathrm{NPK} \mathrm{ha}^{-1}+100 \%$ Vermicompost ha ${ }^{-1}, \mathrm{~T}_{3}-\left(\mathrm{L}_{1} \mathrm{~V}_{0}\right) @ 50 \% \mathrm{NPK}$ $\mathrm{ha}^{-1}+0 \%$ Vermicompost ha ${ }^{-1}, \mathrm{~T}_{4^{-}}\left(\mathrm{L}_{1} \mathrm{~V}_{1}\right) @$ $50 \%$ NPK ha ${ }^{-1}+50 \%$ Vermicompost ha ${ }^{-1}, \mathrm{~T}_{5^{-}}$ $\left(\mathrm{L}_{1} \mathrm{~V}_{2}\right) @ 50 \% \mathrm{NPK} \mathrm{ha}^{-1}+100 \%$ Vermicompost $\mathrm{ha}^{-1}, \mathrm{~T}_{6}-\left(\mathrm{L}_{2} \mathrm{~V}_{0)} @ 100 \% \mathrm{NPK} \mathrm{ha}{ }^{-1}+0 \%\right.$ Vermicompost ha ${ }^{-1}, \mathrm{~T}_{7}-\left(\mathrm{L}_{2} \mathrm{~V}_{1}\right) @ 100 \%$ NPK ha ${ }^{-1}+50 \%$ Vermicompost ha ${ }^{-1}, \mathrm{~T}_{8^{-}}\left(\mathrm{L}_{2}\right.$ $\mathrm{V}_{2}$ ) @ $100 \% \mathrm{NPK} \mathrm{ha}^{-1}+100 \%$ Vermicompost $\mathrm{ha}^{-1}$ having the treatments was replicated thrice. The source of inorganic nutrients sources as Urea, SSP, MOP, and organic nutrients sources as Vermicompost respectively. Basal dose of fertilizer was applied in respective plots according to treatment allocation unifurrows opened by about $5 \mathrm{~cm}$. depth before sowing seeds in soil at the same time sowing of seeds was sown on 
well prepared beds in shallow furrows, at the depth of $5 \mathrm{~cm}$,.

The soil analysis was done in the laboratory of Soil Science, SHIATS.-DU, and Allahabad with following standard methods,

\section{Results and Discussions}

\section{Physical properties of soil at $0-15 \mathrm{~cm}$ depth}

\section{Particle density $\left(\mathrm{g} / \mathrm{cm}^{3}\right)$}

The maximum particle density $\left(2.75 \mathrm{~g} / \mathrm{cm}^{-3}\right)$ was found in treatment $\mathrm{T}_{5}$-[NPK $50 \% \mathrm{RDF}+$ Vermicompost $100 \%$ ] on followed by $\mathrm{T}_{1}$ [NPK 0\% RDF + Vermicompost $50 \%$ ] with $\left(2.64 \mathrm{~g} / \mathrm{cm}^{-3}\right)$ and the minimum value $(2.43$ $\mathrm{g} / \mathrm{cm}^{-3}$ ) particle density was found in treatment $\mathrm{T}_{8}$ [NPK $0 \%$ RDF + Vermicompost $0 \%$ \%] similar results have also been recorded by Bhattacharya et al., (2004) (Table 1).

\section{Bulk density $\left(\mathrm{g} / \mathrm{cm}^{3}\right)$}

The maximum bulk density $\left(1.46 \mathrm{~g} / \mathrm{cm}^{2}\right)$ in depth 0 - 15 found with $\mathrm{T}_{5}$-[NPK 50\% RDF + Vermicompost $100 \%$ ] on followed by $\mathrm{T}_{8}$ [NPK 100\% RDF + Vermicompost 100\%] with $\left(1.43 \mathrm{~g} / \mathrm{cm}^{2}\right)$ and the minimum value $(1$. $16 \mathrm{~g} / \mathrm{cm}^{2}$ ) bulk density was found in treatment $\mathrm{T}_{1^{-}}$[NPK 0\% RDF + Vermicompost $50 \%$ ] similar results have also been recorded by Bhattacharya et al., (2004).

\section{Pore space $(\%)$}

The maximum pore space $(48.75 \%)$ in depth 0 - 15 was found $_{8}$-[NPK $100 \% \mathrm{RDF}$ + Vermicompost $100 \%$ ] on followed by $\mathrm{T}_{7^{-}}$ [NPK 100\% RDF + Vermicompost 50\%] with $(47.50 \%)$ and the minimum value $(42.31 \%)$ pore space was found in treatment $\mathrm{T}_{0}$ (Control) similar results have also been recorded by Bhattacharya et al., (2004).
Chemical properties of soil at $0-15 \mathrm{~cm}$ depth

pH

The maximum $\mathrm{pH}$ (7.67) was found in $\mathrm{T}_{0^{-}}$ (control)on followed by $\mathrm{T}_{5^{-}}$[NPK @ 50\% $\mathrm{RDF}+$ Vermicompost100\%] with (7.56) and the minimum value (7.12) pH was found in treatment $\mathrm{T}_{8}$ (NPK @ 100\% RD+- NPK @ $100 \%$ RDF). Similar results have also been recorded by Bhattacharya et al., (2004), Laxminarayan (2006) (Table 2).

\section{Electrical conductivity $\left(\mathrm{dSm}^{-1}\right)$}

The maximum electrical conductivity $(0.25)$ in depth 0 - 15 was found with $\mathrm{T}_{8}$-[NPK $100 \%$ RDF + Vermicompost 100\%] on followed by $\mathrm{T}_{7^{-}}$[NPK $100 \% \mathrm{RDF}+$ Vermicompost 50\%] with (0.24) and the minimum value (0.20) electrical conductivity was found in treatment T4 [NPK 50\% RDF + Vermicompost $50 \%$ ] similar results have also been recorded by Aphale et al., (2005).

\section{Organic carbon $(\%)$}

The maximum Carbon $(0.84 \%)$ in depth 0 - 15 was found withT ${ }_{8}$-[NPK $100 \%$ RDF + Vermicompost $100 \%$ ] on followed by $\mathrm{T}_{7^{-}}$ [NPK $100 \% \mathrm{RDF}+$ Vermicompost $50 \%$ ] with $(0.75 \%)$ and the minimum value $(0.60$ $\%)$ Carbon was found in treatment $\mathrm{T}_{0}$ (Control). Similar results have also been recorded by Bhattacharya et al., (2004).

\section{Available nitrogen}

The maximum available nitrogen ( $\mathrm{kg} / \mathrm{ah}$ ) $(222.15 \mathrm{~kg} / \mathrm{ha})$ in depth $0-15$ was found with $\mathrm{T}_{8}$-[NPK 100\% RDF + Vrmicompost100\%] on followed by $\mathrm{T}_{7^{-}}$[NPK $100 \% \mathrm{RDF}+$ Vermicompost $50 \%$ ] with $\left(215.90 \mathrm{~kg} \mathrm{ha}^{-1}\right)$ and the minimum value $\left(201.19 \mathrm{~kg} \mathrm{ha}^{-1}\right)$ available nitrogen was found in treatment $\mathrm{T}_{0}$ (Control). 
Table.1 Mechanical analysis of the post-harvest soil

\begin{tabular}{|l|l|l|l|}
\hline S. No. & Soil separates & Age $(\%)$ & Method followed \\
\hline 1. & Sand & 60.0 & Bouyoucous hydrometer \\
\hline 2. & Silt & 20.12 & $(1927)$ \\
\hline 3. & Clay & 11.51 & \\
\hline 4. & Texture of soil & Sandy loam & \\
\hline
\end{tabular}

Table.2 Physical and chemical analysis of pre-harvest soil

\begin{tabular}{|c|c|c|}
\hline Particulars & Rating & Method \\
\hline $\begin{array}{l}\text { 1.Soil pH, Soil water } \\
\text { Suspension }\end{array}$ & 7.19 & Digital pH meter (Jackon 1958) \\
\hline 2. $\mathrm{EC}\left(\mathrm{dS} \mathrm{m^{-1 } )}\right.$ & 0.23 & Digital Conductivity meter (Wilcox 1950) \\
\hline 3. Bulk density $\left(\mathrm{Mgm}^{-3}\right)$ & 1.35 & Graduated measuring cylinder(Black 1965) \\
\hline 4. Particle density $\left(\mathrm{Mgm}^{-3}\right)$ & 2.56 & Graduated measuring cylinder (Black 1965) \\
\hline 5. Pore space $(\%)$ & 47.51 & Graduated measuring cylinder (Black 1965) \\
\hline 6. Organic carbon (\%) & 0.70 & Walkley and Black (1947) \\
\hline 7. Available $\mathbf{N}\left(\mathrm{Kgha}^{-1}\right)$ & 209.25 & $\begin{array}{l}\text { Alkaline Permanganate Method(Subbiah and Asija. } \\
\text { 1956) }\end{array}$ \\
\hline 8. Available $\mathbf{P}\left(\mathrm{Kgha}^{-1}\right)$ & 19.61 & Calorimetric Method (Olsen et al., 1954) \\
\hline 9. Available K $\left(\mathrm{Kgha}^{-1}\right)$ & 132.45 & Flame photometric Method (Toth and Price. 1949) \\
\hline
\end{tabular}

Similar results have also been recorded by Iqbal et al., (2013) and Singh (2003).

\section{Available phosphorus}

The maximum available phosphorus $\mathrm{kg} \mathrm{ha}^{-1}$ $\left(24.03 \mathrm{~kg} \mathrm{ha}^{-1}\right)$ in depth $0-15$ was found with $\mathrm{T}_{8}$-[NPK 100\% RDF + Vermicompost 100\%] on followed by $\mathrm{T}_{7^{-}}$[NPK $100 \% \mathrm{RDF}+$ Vermicompost $50 \%$ ] with $\left(22.87 \mathrm{~kg} \mathrm{ha}^{-1}\right)$ and the minimum value $\left(16 \mathrm{~kg} \mathrm{ha}^{-1}\right)$ available phosphorus was found in treatment $\mathrm{T}_{0}$ (Control). Similar results have also been recorded by Iqbal et al., (2013).

\section{Available Potassium (kg/ha)}

The maximum available potassium $\mathrm{kg} \mathrm{ha}^{-1}$ $\left(147.87 \mathrm{~kg} \mathrm{ha}^{-1}\right)$ in depth $0-15$ was found in $\mathrm{T}_{8}$-[NPK 100\% RDF + Vermicompost100\%] on followed by $\mathrm{T}_{7^{-}}$[NPK $100 \% \mathrm{RDF}+$ Vermicompost 50\%] with (144.27 $\left.\mathrm{kg} \mathrm{ha}^{-1}\right)$ and the minimum value $\left(115.98 \mathrm{~kg} \mathrm{ha}^{-1}\right)$ available potassium was found in treatment $T_{0}$ (Control.) similar results have also been recorded by Khatkar et al., (2009).

It was concluded from trial that the various levels of different sources in the experiment, the treatment $\quad \mathrm{T}_{8}-\mathrm{L}_{2} \quad \mathrm{~V}_{2}$-[@ $100 \% \mathrm{NPK}+100 \%$ Vermicompost.] was found to be the best in increasing Physical and Chemical properties of Soil Bulk density $\left(1.35 \mathrm{Mgm}^{-3}\right)$, Particle density $\left(2.56 \mathrm{Mgm}^{-3}\right)$, Pore Space (47.51\%), pH (7.19), EC (0.23 $\left.\mathrm{dSm}^{-1}\right)$, Organic carbon $(0.70 \%), \mathrm{N}(209.25$ $\left.\mathrm{Kg} \mathrm{ha}^{-1}\right), \mathrm{P}\left(19.61 \mathrm{Kg} \mathrm{ha}^{-1}\right), \mathrm{K}(132.45 \mathrm{Kg}$ $\mathrm{ha}^{-1}$ ), were found to be at par than any other treatment combinations.

Since the result is based on one year experimental data. Further research may be initiated for the establishment of the above findings. 


\section{Acknowledgements}

The authors are thankful to Advisor, Department of Soil Science and Agriculture chemistry, Sam Higginbottom Institute of Agriculture, Technology and Sciences (Deemed-to-be-University), Allahabad, U. P. for taking their keep interest and encouragement to carry the research work.

\section{References}

Aphale, S. L. Stokes, T. S. Black, C. R. Taylor, I. B. and Roberts, J. A. (2005) The role of root to shoot signaling in coordinating responses to soil compaction. Proceedings of the 32nd Annual Meeting of the Plant Growth Regulation Society of America.

Arancon, Q.N. and C.A. Edwards, 2009. The utilization of vermicompost in Horticulture and Agriculture.

Bhattacharya,R. Vedpraksh; Kundu, srivastava, A.K and Gupta, H.S (2004) Effectb of long term manuring on soil organic, bulk density and water retention characteristics under soyabeen- wheat cropping sequence in north -western Himalayas journal of the Indian society of soil science 52:238242.

Black, C.A. (Ed) (1965) Method of soil analysis Vol. 1. Am. Soc Agron. Madison, Wisconsin, V.S.A.

Bouyoucos, G.J. (1927). The hydrometer as a new method for the mechanical analysis of soils Sci. 23: 343-353.

Edwards CA, Jeyaraaj R, Indira AJ (Eds.) 2009 Vermitechnology in Human welfare. Rohini Achagam, Coimbatore, Tamil Nadu, India, pp: 98-108.

Iqbal, M., Khan, A.G., Hassan, A. and Islam, K.R. (2013) Tillage and Nitrogen Fertilization Impact on Irrigated Corn Yields, and Soil Chemical and Physical Properties Under Semiarid Climate J. of
Sustainable Water. Sc. Mang. 1 (3): 9098,

Jackson, M.L. (1958). Soil Chemical Analysis. Prentice Hall of India Private Ltd., New Delhi.

Khanday, A.B.S; Sharma, U; Dubey, and Bhardawaj, S.B (2012) Effect of different fertilizer and irrigation management system on physicchemical properties and yield of maize cropping sequence. Indian journal of Agronomy, 57(3): 222-228.

Khatkar, Y., Dawson, J., Rao, Z.K.K., Dixit, P.M. and Khatkar, R. (2009) Effect of nitrogen, phosphorus and sulphur fertilization on growth and yield of maize (Zea mays) Inter. J. of Agri. Sc., Vol.5 Issue 2: 396-39.

Lavelle P, Martin M. (1992). Small scale and large scale effects of endogeic earthworms on soil organic matter dynamics in soils of the humid tropics. Soil Bio and Biochem. 24, 81-96.

Laxminarayan (2006) Effect of integrated use of inorganic and organic manure on soil properties yield and nutrient uptake in altisols to mizorum Journal of the Indian society of soil Science 54: 120123.

Liu, M., F.Hu, X. Chen, Q. Huang, J. Jiao, B. Zhang and $\mathrm{H}$. Li, 2009. Organic amendments with reduced chemical fertilizer promotes soil microbial development and nutrient availability in a subtropical paddy field: the influence of quantity, type and application time of organic amendments. Appl Soil Ecol, 42: 166-175.

Lourduraj CA, Yadav BK, (2005). Effect of vermicompost application on soil and plant growth. Verms and vermitechnology. A.P.H. Publ. Cor. 5, Ansari Road, Darya Ganj, New Delhi. pp 81-96

Melero, M., K. Vanderlinden, J.C. Ruiz and E. Madejon, 2008. Long-term effect on 
soil biochemical status of a vertisoil under conservation tillage system in semi-arid Mediterranean conditions. European journal of soil biology, 44(4): 437-442.

Olsen, S.R., Cole, C.V., Watanhe, F.S. and Dean, L.A. (1954). Estimation of available phosphorus in soil by interaction with sodium bicarbonate. U.S. Deptt. Agri. Circ. 939.

Prabha LM. (2006). Vermitech- A potential technology for the conversion of wastes into biofertilizer Ph.D. Thesis Department of Biochemistry, Kongunadu Arts and Science College, Coimbatore, Tamil Nadu, India. pp. 7986.

Rai, Mangla (2006) Effect of integrated nutrient management local and hybrid varieties of maize (Zea mays L.) yield. Hand Book of Agriculture. pp 872-886.

Ramasamy, P. K., Baskar K. and Ignacimuthu, S. (2011). Influence of vermicompost on kernel yield of Maize (Zea mays L.). Elixir Agriculture, 36(3): 119-3121.

Singh, K.P., A. Snman, P.N. Singh and T.K. Srivastava, 2007. Improving quality ofsugarcane-growing soils by organic amendments under subtropical climatic conditions of India. Biol Fertil Soils, 44: 367-376.

Singh, R. N., Sulatiya, R., Ghata K. R., S. A. (2003) Effect of higher application of Nitrogen and potassium over recommended level on growth yield and yield attribute of late sown winter maize (Zea mays L.) crop research, Hissar, 26: 1, 71-74.

Subbaiah, B.V. and Asija, C.L. (1956). A rapid procedure for the estimation of available nitrogen in soil. Current Sci., 25: pp 415-426.

Toth, S.J. and Prince, A.L. (1949) Estimation of Cation exchange capacity and exchangeable $\mathrm{Ca}, \mathrm{K}$ and NA content of soil by flame photometer technique. Soil. Sci. 67: pp 439-445.

Walkley, A. and Black, C.A. (1947) Critical examination of rapid method for determination organic carbon in soil, effect on variation in digestion condition and of inorganic soil constituents. Soil. Pp 632-651.

Wilcox, L.V. (1950) Electrical conductivity, Amer. Water Works Assoc. J. 42: 775776.

\section{How to cite this article:}

Vinod Kumar Prajapati and Narendra Swaroop. 2018. Effect of Different Levels of NPK and Vermicompost on Physico-Chemical Properties of Maize [Zea mays (L.)] Cv. MM2255. Int.J.Curr.Microbiol.App.Sci. 7(02): 1405-1410. doi: https://doi.org/10.20546/ijcmas.2018.702.169 